\title{
Group Development in Speaking Classroom for Adult Learners
}

\author{
Hasbi Noris Sigara \\ Universitas Muhammadiyah Malang \\ Malang,East Java, Indonesia \\ E-mail: $\underline{\text { Habib@yahoo.com }}$
}

Received: January 102018
Accepted: January 172018

Published: February 9, 2018

Doi : http://dx.doi.org/10.30587/jetlal.v2i1.2430

\begin{abstract}
Group Development is a term used to indicate the patterns in the way groups of people change over time and make decisions. The study of group developments can be useful in speaking classroom especially in observing adult learners' behaviors. Furthermore, it is also beneficial in understanding the process of decision making in group behavior especially in regarding speaking ability as one of the measurements in knowing someone's language proficiency. People tend to consider speaking as the most important skill that they can acquire and they can assess their progress in communication. This article discusses on how group development create interaction and behavior decision in speaking classroom for adult learners.
\end{abstract}

Keywords: group development, speaking classroom, adult learner

\section{Introduction}

A group consists of two or more individuals that they will interact and get relationship between them (Donelson. 2010:3). We can tell a group has "powerful social units" (Dornyei. 2003:12) and it has the characteristics to influence the classroom activity during they interact in the class. From those experts, we can assume that group is a collection of people who interact with one another; accept rights and obligations as members. Inside the groups there are different characteristics that may influence the learning process. In this case, we will talk about group development. Group development concern how groups are formed, what is their structure and which processes are followed in their functioning. Thus, it is concerned with the interactions and forces operating between groups. The position of the teacher in group development as a central figure and the student become the active members of the group. The combination between the teacher and the student can emerge as a powerful social unit (Dornyei. 2003:4).

In speaking class usually if teacher create group in the class, the member of the group cannot speak up although they are adult learners. It is only the student that has good ability in speaking raise to speak up. It is so difficult to make all the member of the class speak up. According to Robin Alexander (2004), students have to give 'communicative right'; they are regarded as having something to contribute to a lesson, rather than being mere receivers of knowledge. It also creates an environment of constructive feedback in which tough questions are posed, forcing students to learn to tackle issues on their feet and to articulate them orally.

For adult learners, speaking classroom practice will be useful if we can analyze about their characteristic. According to Jeremy Harmer (2001:40), adult learners may have experienced failure or criticism at school which makes them anxious and under confident about learning a language. Many older adults worry that their intellectual powers may be diminishing with age-they are concerned to keep their creative power alive, to maintain a sense of generativity (Williams and Burden 1997:32). Jeremy Harmer (2001:40) also said that good teachers of adults take all of these factors into account. It's our opportunity as a teacher to involve and always encourage our student in learning process and make them always curious to know and to speak.

Based on the student needs, by analyzing the group development, the teacher will know about the students development from daily activity of the group. It makes important for the teacher to know about group development especially in speaking classroom, it become significant. This article want to give the important of group development in speaking classroom for adult learners.

\section{A. Group Development}


Group take time to develop. It is impossible to specify how long the group will develop. It depends on the size, frequency of interaction, structural features, and so on. Bruce Tuckman created a model in 1965 outlining four steps which was later completed in 1977 by adding a fifth step that outlines group development. Each step has its own set of challenges that need to be faced before moving on to the next. Here is a look at the five steps of group development:

1. Forming: the first stage is creating a team, the formation phase of group development is centered on getting to know each other. Typical features of this phase are politeness, tentativeness and significant dependency on the leader (that is the teacher).

2. Storming: During the storming stage, participants are becoming more familiar with each other and feel free to express their individuality; differences and conflicts become common, arising from disagreement and competition among members and between group and the leader. Group is likely to make itself free from its dependence on the leader - conflicts between the teacher and some students often happen. Difficult participants can often emerge. A process frequently observed in this stage is sub grouping.

3. Norming: The group begins to structure itself; responsibilities are divided; members start to adopt agreed group roles and accept common rules.

4. Performing: The performing phase is characterized by increasing in cooperation and decrease in emotionality. The group has developed internal structure and has agreed on norms, roles and decision-making procedures.

5. Adjourning: is the final stage and when the group comes together to celebrate the efforts of one another for completing the project. Adhesive groups will always come together at the end of a project and commend each other for their efforts. Adjourning introduced in as the final stage of group development

The other step of group development also mention by Ehrman and Dornyei (1998) that they distinguish four primary group developments. They are group formation, transition, performing, and dissolution.

\section{Group Formation}

In this phase, the formation for group development makes the student try to know each other. The teacher roles here try to build a pleasant atmosphere in the classroom in order to reduce the anxiety level of the student itself. The characteristics of the group members will depend on who's the leader that designated (Wheelan. 1994). So, a good selection of the leader will drive the group in to success group.

\section{Transition}

In this phase, the students often get conflict rather than peaceful things. The main point of this phase for the group is to make decision about how this phase operates and also the role of the members (Dornyei and Muphey. 2003: 52). Because of this, the members and the leader sometime have debate activity about how decide the role. But it is usual; they will argue how to solve the problems. It's good actually if the group has debate, different opinion among the members, and try to find a solution together, not always avoid the disruption. It makes the group stronger than usual.

\section{Performing}

After doing the first and second step above, the group already has a good foundation to stand or we can call "mature" group. It means that they strong enough as a group. Performing group characterized with "increase" in cooperation and task orientation and "decrease" emotionality (Dornyei and Murphey. 2003:54).

\section{Dissolution}

This is the last phase of group development. Dissolution in group development means that the members will try to flash back what they have done, to see what their deficiency, and also evaluate what they should do in the future after the course done. The dissolution phase will help the group to integrate what they have done and also help to give point of view about the future (Dornyei and Murphey. 2003:55). In the dissolution, the members already separated and they will have appointment such kind of reunion. But to maintain their ability about L2 competence, the student still needs some advice and even guideline from the teacher.

In line with Tuckman (1965), the first two phases of group development are related to Dornyei's (2003) principles of promoting group acceptance. These principles include: learning about each other, proximity, and contact. Learning about each other makes the students interact freely in the class. Their interactions can be asking their hobbies, 
what they do in their free time, and what subject that they like and dislike. That's activities will give chance to the students to interact one another. While the activities running, sometimes they get something confuse, that makes they face information gap. This information gap can be reduce by asking other student in the class, perhaps the other students have the answer of their problem that makes them confuse. Usually after that activity, they will invite the whole students' participation. They will ask something interest to their friends, and the members of the class will try to answer that question. Those activities will guide the students' interactions.

Proximity is related how to promote students to have different friends when they interact in classroom discourse. It means that they have to interact with all students in the class. To create the proximity in the class, we can regularly re arrange the seats. We can rearrange in to half circular seats, full circular, ad hock, and the others arrangements seats to provide interaction for all students. Sometimes the students still interact with same students although we already rearrange the seats. So, we have to do something that we called regularly regroup the students. We move the member of some group to the other group. It makes them interact with the different people without exception.

Beside proximity, contact also related to group development that provide by Tuckman. Students can contact spontaneously in their daily activities. We have to set relaxing situation with students' interaction. Make them relax will guide them easily to break their shyness to interact, the interaction that they have made will make them comfortable in the class. Students' classroom activity sometime makes them bored, so we have to ask them to follow other activities beside study in the class. By having extracurricular activities will give them extra knowledge, make them have extra abilities, and perhaps guide them into extraordinary students. So many kinds of extracurricular activities can choose by the students. The can choose based on their favor. For example, student that loves to sing can follow choir activity or create band in the school. Regularly the student study at the class, but make them realize about what they have studied, we can conduct outing class. In outing class activity, we can present the reality to the students. Activities outside of the class give them different view of the object that they usually study from the book. For example, the students study about direction. We can ask them to look the direction that they can find at the school. After they get some direction, they can tell how to go to that direction from where they stand.

It is important to say that not all adult classes pass through all these stages. For example, the class group can miss some of these stages or get stuck in other; the group members may sit through the life of the group by basically remaining strangers (which rather common in seminar groups in higher education) (Dornyei and Murphy 2003: 57). Nevertheless, the knowledge of these stages and principle of group development can help the teachers to prevent feelings of confusion and blaming themselves, especially in more disruptive phase of the group life.

\section{B. Speaking Classroom Activity for Adult Learners}

Speaking as we know is one of the major skills in English. Speaking it's about producing and receiving and also processing information (Burn \& Joyce, 1997). Learners consequently often evaluated their success in studying language learning especially for English course from how well they have improve their spoken language. In designing speaking classroom activity for adult level, actually they do not know about English as well for the first time because they come from different place, different culture, and even different language. Getting students to speak in first meeting class may be the most difficult task for the teacher. Sometime they get panic if the teacher asks them to speak or respond something. In adult level, we can start to do such kind of knowing each other's name (Dornyei and Murphey. 2003:26). By knowing about the students' name, they feel recognize in the group of the class. Another activity for speaking classroom is ice breaker (Dornyei and Murphey. 2003:29). Based on Frank and Rivonlucri (1991), ice breaker can make the students easily to identify each other. Identifying the whole student in the class can build personal relationship in the first meeting. It is important to make the student feels at home in the class (Dornyei and Murphey. 2003:30), they can get fast interaction among the students in the class because ice breaker seems like sharing information. It also decreases the shyness of the student at the first meeting.

Therefore, this part mainly discusses the theory of adult learners. Acording to Lado (1961), adult and older people have the problem of transfer of the habits of the native language more than younger people. To be sure, the adults may be less motivated than the schoolboy (Cronbach, 1963). They sometime do not want to experience something new which needs accuracy and concentration. Besides, Lado (1961) states that they have maximum difficulty in remembering the sounds, they finally learn to hear and produce, and they have the same difficulty establishing the new sounds as habit of speech. Knowing this idea, it is significance to discover a technique which will help and facilitate adults to learn English especially for speaking skill.

Now we move to talk about the characteristics of adult learners. Adult learners have several special characteristics (Jeremy Harmer. 2003:40):

a. Adult learners can imagine sometnhing althoug it still abstract things.

b. Adult learners have so many experiences to talk about 
c. The adults always expect to become something in their learning process.

d. Adults learners more disciplined than some teenagers, and also their mentality already mature to face something bored in learning process

e. Because the adult leraners have so many experinces, it will easier for the teacher to give activity wider than teenagers.

f. Unlike young children and teenagers, they often have a clear understanding of why they are learning and what they want to get out of it.

Despite the fact that adults learners have a lot of limitations, they actually still have a big motivation to learn. Motivation is one of the greates influences off effective learning. Knowles (1977) describes that adults are motivated to learn because of a concern with upward occupational mobility, and a sense of personal achievement, satisfaction, and self fulfillment. The teachers duty always to support them and provide the best circumtance to learn English. By knowing this characteristics, then the teachers are able to adjust the teaching technique with their students so that learning goals achieved completely. It will help the teacher develop the students group using the step that already mention above.

\section{Conclusion}

Group development in speaking classroom for adult learners can be useful strategies in student practice, student activation in classroom, and student curiosity in learning and speak a language. In teaching adult learners we have to know what their advantages and what their disadvantages. One of the advantages is adult learners already has a goal their learning process. But they has several weakness, one of them is lack of remembering about language. Although adult learners have so many limitations, they still have big motivation to study about language. In order to make this strategies become success, there are five steps to do; forming, storming, norming, performing, and adjourning. Other additional steps also support the five primary steps itself, they are group formation, transition, performing, and dissolution. We have to know about the characteristic of adult learners first and the step how to apply group development in speaking classroom practice. This study hopefully can give something beneficial to the readers and also to another researcher.

\section{References}

Alexander, R. 2004. Towards Dialogic Teaching: rethinking classroom talk (York, Dialogos).

Brown, W. Nina 1992. Teaching Group Dynamics: Process and Practices. British Library Cataloguing.

Burns, Anne and Joyce Hellen 1997. Focus on Speaking. North Ryde, N.S.W. : National Centre for English Language

Teaching and Research.

Cronbach, Lee, J 1963. Educationa Psychology. United States: Harcourt, Brace and World Inc.

Dornyei, Zoltan 2001. Motivational Strategies in Language Classroom. Cambridge University Press.

Dornyei, Zoltan and Murphey 2003. Group Dynamics in The language Classroom. Cambridge University Press.

Ehrman, M. E. and Z. Dornyei 1998. Interpersonal Dynamics In Second Language Education: The Visible and Invisible

Classroom. Thousand Oaks, CA: Sage.

Forsyth, R. Donelson 2010. Group Dynamics. Wadsworth, Cengage Learning.

Frank, Christine and Mario Rinvolucri 1991. Granmar in Action Again! (Langauge Teaching Methodology Series: ELT Classroom Techniques And Resources). Prentice Hall.

Harmer, Jeremy 2001. The Practice of English Language Teaching $3^{\text {rd }}$ edition. Longman. 40.

Knowles 1977. Principles from Adult Learning Theory, Evidence-Based Teaching, and Visual Marketing: What are the Implications for Toolkit Development?. ebp.networkofcare.org/.../Adult_Learning_Theory_2497281.pdf.\{Online\} Available. accessed on December 20, 2011.

Lado, R (1961). Language Testing. New York. Mc-Graw Hill

Tuckman, Bruce 1965-1977. Health Organizations: Theory, Behavior, and Development. John and Bartlett Publisher, LLC.

Wheelan, Susan A. 1994. Group Process: A Developmental Perspective. Needham Height, MA: Allyn \& Bacoon: The Simon \& Schuster Education Group. 